\title{
The Effect of Stopping Dapsone Treatment for Two Months and then Restarting it in Full Dosage in Patients with Moderately Severe Erythema Nodosum Leprosum*
}

\author{
J. M. H. PEARSON $\dagger$ \\ Physician, Leprosy Research Unit, \\ National Leprosy Control Centre. \\ Sungei Buloh, Malaysia $\ddagger$ \\ and \\ H. S. HELMY \\ Medical Officer, National Leprosy \\ Control Centre, Sungei Buloh, Malaysia
}

\begin{abstract}
Nine patients suffering from persistent, moderately severe erythema nodosum leprosum (ENL) were included in this study. During a period of 8 or 10 weeks when anti-leprosy treatment with dapsone was replaced by a placebo capsule, there was a fall in the severity of the ENL which just attained statistical significance. When dapsone treatment was restarted in full dosage (100 mg daily), using a capsule identical to the placebo, there was no effect on the ENL for the first 2 weeks, and a slight (but statistically insignificant) increase in its severity thereafter.
\end{abstract}

Erythema nodosum leprosum (ENL) was first recognized, and indeed named, long before the development of chemotherapy against leprosy (Murata, 1912). However, with the introduction of effective anti-leprosy drugs, ENL became a more common and much more serious problem in the management of patients with lepromatous leprosy. The sulphone drugs, and particularly dapsone $\left(4^{\prime}, 4\right.$ diaminodiphenyl sulphone, DDS) were the first such drugs to be used; at first the increased incidence of ENL was considered to be a complication caused by the drug itself, and the practice of discontinuing dapsone treatment in the presence of ENL was introduced.

It has, however, since become apparent that treatment with any effective anti-leprosy drug is liable to be associated with ENL; and moreover the

* Received for publication 18 January, 1973.

$\dagger$ Requests for reprints of this paper should be addressed to Dr J. M. H. Pearson at the National Institute for Medical Research, Mill Hill, London N.W.7. England.

$\ddagger$ Present address: Armauer Hansen Research Institute, P.O. Box, 1005, Addis Ababa, Ethiopia. 
mechanism of ENL, long suspected to be "allergic", is now better understood, and appears to be a manifestation of the toxic effect of antibody/antigen complexes (Wemambu et al., 1969). Thus the relationship between the antileprosy drug and ENL is not a direct one, but indirect, due to the effect of the drug in causing the death of the leprosy bacilli. Subsequent autolysis and disintegration of the bacilli with the release of antigenic material is probably not in any way affected by anti-leprosy treatment.

Despite a strong general opinion that ENL becomes more severe when treatment with dapsone in high dosage is employed, and less severe when this treatment is discontinued, there has been no adequate trial of the effect of these manoeuvres on the severity or frequency of episodes of ENL. Recently, however, methods have been developed at the Leprosy Research Unit, Sungei Buloh, Malaysia, for testing the effect of drugs against ENL, and the technique has been applied to evaluate the action of thalidomide (Pearson and Vedagiri, 1969; Waters, 1971) and clofazimine (Helmy, Pearson and Waters, 1972). It has been shown to be sufficiently sensitive to detect the beneficial effect of clofazimine in a dosage of $300 \mathrm{mg}$ daily within the first 3 or 4 days of starting treatment. In this paper we describe a trial in which we used the method to assess the effect of discontinuing and then re-introducing dapsone treatment in a group of patients with active, fairly continuous, and moderately severe ENL.

\section{Patients and Methods}

The patients were selected from among those attending the Research Unit; some were in hospital wards, but the majority were living in quarters within the hospital grounds and attending Research-Unit wards for treatment. All the patients had been suffering from ENL for at least 6 months prior to the study, and it was known therefore that their reaction was fairly continuous and did not vary greatly in severity from week to week. One patient required prednisolone during most of the trial period, but in the others the reaction was usually controlled satisfactorily by analgesics and antimonials (stibophen), though 3 patien ts had to have prednisolone for periods of several weeks during the trial.

The trial followed the general pattern of our previous studies, i.e. standard anti-ENL treatment was employed in addition to the trial treatment, and the benefit of the trial drug was measured by its sparing effect on the requirement of the standard drugs.

\section{DESIGN OF THE TRIAL}

The trial was divided into 4 periods as follows.

Period l-Initial control period (weeks 1-4); during this time all patients continued on their normal anti-leprosy treatment.

Period 2-Placebo period (weeks 5-12 or 5-14); all patients received one placebo capsule daily.

Period 3-Dapsone period (weeks 13-16 or 15-16); in this period patients received every day a capsule, identical in appearance to the placebo but containing dapsone, $100 \mathrm{mg}$.

Period 4-Final control period (weeks 17-20); the patients reverted to their usual treatment, as in the initial control period.

Patients received the dapsone capsule for either 2 or 4 weeks according to a random distribution plan, the key to which was not known till the trial was 
completed and results tabulated. The trial was thus a blind study of the effect of stopping anti-leprosy treatment, and a double-blind trial of the effect of restarting dapsone in full dosage.

During the period of the trial all the patients attended the Research Unit daily (except Sundays) at about 2 p.m. Here their temperature was recorded, and during weeks 5-16 a capsule was issued and seen to be swallowed.

All patients were seen by a doctor twice a week and the severity of ENL, presence of nerve pain or tenderness, and treatment received since the previous visits were recorded. Every 2 weeks and sometimes more frequently, the urine was checked for dapsone content. White blood-cell counts were performed approximately every 2 weeks; but for technical reasons the timing was irregular and the results, which do not affect the findings, are therefore not included.

\section{METHODS OF SCORING}

On each occasion when the patient was examined the clinical findings (i.e. the number of ENL lesions, "activity", and extent of nerve involvement) were recorded. The treatment received during the period since the previous assessment was also noted, as were also the maximum temperature and the results of the W.B.C. count if performed.

Of these assessments of the severity of ENL, only the temperature and W.B.C. count are objective; the most important parameters (i.e. the number and "activity" of lesions and the presence of nerve pain and tenderness) can only be subjective judgements. However, with experience, assessments and treatment become more consistent and thus it is possible to evolve a reproducible "scoring system" (see Table 1) allotting numerical values to the clinical findings.

While effective anti-reaction treatment is being administered the reaction is decreased, and the "clinical score" alone is not a true index of the severity of the ENL; it is necessary therefore to allot additional "points" for anti-ENL treatment. Moreover, if the score is to represent the true severity of the ENL, the total score (for clinical severity plus treatment) should amount to roughly the figure that the clinical score would have reached in the absence of anti-ENL treatment. The system shown in Table 1 was designed to achieve this balance.

\section{Results}

A total of 14 patients were admitted to this study, but 2 were withdrawn during the period of the trial-1 patient on account of haematemesis, and the other because she was found to be pregnant. A further 3 patients completed the trial but were not included in the analysis-in 2 cases because tests for the presence of dapsone in the urine indicated that it was being surreptitiously taken during the period of placebo treatment; in the 3 rd case the tests suggested that in the initial control period the patient was not taking the full dosage of dapsone prescribed.

Clinical details of the 9 patients finally included in the study are given in Table 2. The diagnosis both of lepromatous leprosy and of ENL was confirmed histologically, in the latter case just before or during the course of the trial. The period of anti-leprosy treatment varied between 2 and 5 years, except that one patient who had been treated with thiambutosine for 11 years developed resistance to this drug, and had received dapsone for 9 months before the start of the trial. The period during which the patients had been suffering from ENL 
TABLE 1

Clinical grading of ENL and scores allotted for different parameters on each twice-weekly examination

\begin{tabular}{|c|c|c|c|c|c|c|c|c|c|}
\hline \multirow[b]{2}{*}{ Score } & \multicolumn{2}{|c|}{ ENL Lesions } & \multirow{2}{*}{$\begin{array}{c}\text { Nerve } \\
\text { involvement }\end{array}$} & \multirow{2}{*}{$\begin{array}{l}\text { Maximum } \\
\text { temp. } \\
\text { recorded }\end{array}$} & \multicolumn{3}{|c|}{ Anti ENL treatment } & \multirow{2}{*}{$\begin{array}{c}\text { "Nerve } \\
\text { injection"c }\end{array}$} & \multirow{2}{*}{$\begin{array}{l}\text { Total white } \\
\text { blood cell count }\end{array}$} \\
\hline & Number & Activity & & & Stibophen & ACTH & Prednisolone ${ }^{b}$ & & \\
\hline 0 & None & & None & Below 99 & Nil & $\mathrm{Nil}$ & Nil & Nil & $0-9900$ \\
\hline 1 & Few & Indolent & 1 tender & 99 to $99^{8}$ & $1-4 \mathrm{cc}$ & $25 \mathrm{IU}$ & $0-19 \mathrm{mg}$ & 1 injection & $10,000-13,900$ \\
\hline 2 & $\begin{array}{l}\text { Moderate } \\
\text { number }\end{array}$ & $\begin{array}{c}\text { Moderately } \\
\text { active }\end{array}$ & $\begin{array}{l}\text { More than } 1 \\
\text { tender }\end{array}$ & 100 to $100^{8}$ & $5-8 \mathrm{cc}$ & $50 \mathrm{IU}$ & $20-29 \mathrm{mg}$ & 2 injections & $14,000-17,900$ \\
\hline 3 & Many & $\begin{array}{l}\text { Active, a few } \\
\text { ulcerating or } \\
\text { almost } \\
\text { ulcerating }\end{array}$ & 1 painful & 101 or over & - & $75 \mathrm{IU}$ & $30-39 \mathrm{mg}$ & 3 injections & 18,000 or more \\
\hline 4 & Many & $\begin{array}{c}\text { Active, many } \\
\text { ulcerating }\end{array}$ & $\begin{array}{l}\text { More than } 1 \\
\text { painful }^{a}\end{array}$ & - & - & $100 \mathrm{IU}$ & $40-49 \mathrm{mg}$ & 4 injections & - \\
\hline
\end{tabular}

${ }_{b}^{a}$ Other nerves may or may not be tender.

${ }^{b}$ The score increases with further increase of dosage: i.e. $70-79 \mathrm{mg}=7$.

$c$ This consists of perineurial injection of hydrocortisone acetate, $25 \mathrm{mg}$ in $2 \%$ procaine with added hyalase. 
TABLE 2

Details of trial cases.

\begin{tabular}{|c|c|c|c|c|}
\hline Case no. & $\begin{array}{l}\text { Duration of } \\
\text { treatment } \\
\text { (years) }\end{array}$ & $\begin{array}{l}\text { Dosage of DDS } \\
\text { (mg twice weekly) }\end{array}$ & $\begin{array}{l}\text { Duration of } \\
\text { ENL (years) }\end{array}$ & $\begin{array}{l}\text { Clinical assessment } \\
\text { at finish of trial }\end{array}$ \\
\hline 16241 & 2 & 100 & $11 / 2$ & Improved \\
\hline 16011 & 5 & 100 & $41 / 2$ & Improved \\
\hline 15657 & 4 & 100 & 2 & Improved \\
\hline 16206 & $2^{1 / 2}$ & 100 & 2 & Worse \\
\hline 49125 & $31 / 2$ & 100 & $31 / 2$ & No change \\
\hline 13399 & 11 & 100 & $1 / 2$ & Worse \\
\hline 15631 & 3 & 50 & 3 & No change \\
\hline 16359 & 5 & 100 & 2 & Worse \\
\hline 16030 & $4 \frac{1}{2}$ & 100 & $4^{1 / 2}$ & Not assessed \\
\hline
\end{tabular}

${ }^{a}$ This is an assessment of the underlying leprosy condition, and not of the ENL.

ranged from 6 months to $4 \frac{1}{2}$ years; but none had received treatment with clofazimine or thalidomide during the 3-months' period before the trial started. All the patients were receiving dapsone initially-the dosage is shown in Table 2 .

Because the study included a 2-month period during which these patients were receiving no anti-leprosy treatment, the state of the leprosy was assessed by an independent clinical assessor at the start and finish of the trial. These findings are shown in Table 2; 3 patients were considered improved, 2 unchanged, and 3 worse. (One case was not assessed.)

The total scores for all patients by all criteria are shown in Table 3; they are divided into 9 periods of 2 weeks each. These periods consist of the first 4 weeks initial control period, and the first 8 weeks of placebo treatment. At this point 4 patients restarted dapsone, the remaining 5 continuing on the placebo for a further 2 weeks. Thus the scores for the first 2 weeks on dapsone were in 4 cases those of weeks 13 and 14, and in the other 5 cases of weeks 15 and 16; in 5 cases the final 2 weeks on placebo have been omitted from this Table, and in 4 cases the second 2 weeks on dapsone, $100 \mathrm{mg}$ daily. The final control period, when the

TABLE 3

Total scores of all patients throughout the trial period

\begin{tabular}{|c|c|c|c|c|c|c|c|c|c|}
\hline \multirow[b]{2}{*}{ Weeks } & \multicolumn{2}{|c|}{$\begin{array}{l}\text { Initial control } \\
\text { period }\end{array}$} & \multicolumn{4}{|c|}{ Placebo period } & \multirow{2}{*}{$\begin{array}{l}\text { 1st } 2 \text { weeks } \\
\text { on DDS } \\
13-14 / 15-16\end{array}$} & \multicolumn{2}{|c|}{$\begin{array}{c}\text { Final control } \\
\text { period }\end{array}$} \\
\hline & $1-2$ & $3-4$ & $\widetilde{5-6}$ & $7-8$ & $9-10$ & $11-12$ & & $17-18$ & $19-20$ \\
\hline ENL & 104 & 79 & 77 & 70 & 45 & 62 & 44 & 107 & 121 \\
\hline Nerves & 10 & 3 & 15 & 9 & 3 & 5 & 6 & 25 & 15 \\
\hline Temperature & 20 & 8 & 13 & 16 & 18 & 11 & 13 & 21 & 13 \\
\hline Steroids & 42 & 25 & 32 & 23 & 22 & 36 & 25 & 13 & 13 \\
\hline Stibophen & 32 & 18 & 25 & 18 & 14 & 13 & 14 & 20 & 16 \\
\hline Total & 208 & 133 & 162 & 137 & 102 & 127 & 102 & 186 & 178 \\
\hline
\end{tabular}

${ }^{a}$ In 4 cases, weeks 13 and 14 ; In 5 cases, weeks 15 and 16 . 
dosage of dapsone was the same as in the initial control period, was in all cases weeks 17 to 20 .

Comparing the scores for the initial and final control periods, it will be seen that although there is a wide range of totals (133 to 208), the average fortnightly scores for the initial and final control periods are very close to each other (171 and 182 respectively). It seems likely, therefore, that there was no serious alteration in the severity of the ENL during the 20-week period of the trial.

The total scores during the period of placebo treatment also show a wide range (102 to 162): the average is 132 , which is $25 \%$ below the scores for the initial and final control periods. If the figures for weeks 5 and 6 , when the patients could still not have excreted all their dapsone, are excluded, the average is 122 (a fall of $32 \%)$.

The period of 2 weeks when dapsone was reintroduced, in a dosage of $100 \mathrm{mg}$ daily, was not marked clinically by a recrudescence of the ENL, and the total scores for this period of 2 weeks remained in the same range as those during the placebo period. This absence of acute flare-up of ENL is confirmed by Table 4, in which the scores for the last week of placebo treatment and the first week of dapsone treatment are shown.

The fortnightly scores for the last 4 weeks of placebo and the first 6 weeks of re-starting dapsone therapy are shown in Table 5. They confirm that there was a

TABLE 4

Total scores during the last week of placebo treatment and the first week of DDS treatment

\begin{tabular}{lcc}
\hline & $\begin{array}{c}\text { Score during last } \\
\text { week of placebo }\end{array}$ & $\begin{array}{c}\text { Score during first } \\
\text { week of DDS }\end{array}$ \\
\hline Severity of ENL & 27 & 15 \\
Nerve involvement & 0 & 2 \\
Maximum temperature & 6 & 7 \\
Dosage of steroids & 7 & 9 \\
Dosage of stibophen & 4 & 4 \\
\multicolumn{1}{c}{ Total } & 44 & 37 \\
\hline
\end{tabular}

TABLE 5

The effect of restarting DDS on the severity of ENL

\begin{tabular}{|c|c|c|c|c|c|}
\hline & \multicolumn{2}{|c|}{ Placebo period } & \multicolumn{3}{|c|}{ Period on DDS treatment } \\
\hline & $\begin{array}{l}\text { Next to last } \\
2 \text { weeks }\end{array}$ & Last 2 weeks & First 2 weeks & Second 2 weeks & Third 2 weeks \\
\hline ENL & 52 & 48 & 46 & 92 & 107 \\
\hline Nerves & 5 & 1 & 6 & 19 & 17 \\
\hline Temperature & 17 & 12 & 14 & 15 & 13 \\
\hline Steroids & 36 & 25 & 25 & 13 & 21 \\
\hline Stibophen & 14 & 13 & 14 & 24 & 15 \\
\hline Total & 124 & 99 & 105 & 163 & 173 \\
\hline
\end{tabular}


delay of some 2 weeks after re-starting dapsone before the scores increased. This delay is still seen if the 2 groups of patients are tabulated separately (Table 6), though in one group the score showed some increase in the initial 2 weeks of dapsone. The total scores were higher in fortnights 9 and 10, though the dapsone dosage was only about one-quarter of that received in fortnight 8 .

TABLE 6

Total scores during trial period

\begin{tabular}{|c|c|c|c|c|c|c|c|c|c|c|c|}
\hline \multirow[b]{2}{*}{ Group } & \multirow{2}{*}{$\begin{array}{l}\text { No. of } \\
\text { cases }\end{array}$} & \multicolumn{10}{|c|}{ Fortnight of trial } \\
\hline & & 1 & 2 & 3 & 4 & 5 & 6 & 7 & 8 & 9 & 10 \\
\hline $\begin{array}{l}\text { Cases restarting DDS } \\
\text { in fortnight } 7\end{array}$ & 4 & 110 & 66 & 69 & 27 & 22 & 25 & 42 & 50 & 63 & 65 \\
\hline $\begin{array}{l}\text { Cases restarting 1)ISS } \\
\text { in fortnight } 8\end{array}$ & 5 & 96 & 67 & 93 & 109 & 80 & 102 & 74 & 63 & 113 & 108 \\
\hline
\end{tabular}

\section{Discussion}

Despite the small number of patients included in this trial, two negative findings are quite clear: (1) there was not a dramatic fall in the severity of ENL when dapsone was discontinued; and (2) there was not an acute exacerbation of ENL when dapsone was restarted in maximal dosage after 2 months of treatment with a placebo.

Both of these findings are in agreement with current understanding of the bacteriostatic chemotherapeutic action of dapsone (Bushby, 1964) and of the pathogenesis of ENL (Wemambu et al.. 1969). The only reservation that might be made is that these patients were a selected group, with a particular severity of ENL. The selection was deliberate; they were chosen as being those most likely to demonstrate minor changes in the severity of ENL (Pearson and Vedagiri, 1969). It is possible, though unlikely, that different selection would alter the results.

Positive findings are harder to evaluate. The figures give the impression that there was a mild reduction in the severity of the ENL during the placebo period and an increase on restarting dapsone, with a lag period in each instance of 2 weeks or so. This impression is not contradicted by study of the figures for individual cases. The number of patients included in this study is small for statistical analysis, but the fall in weeks 9 to 12 just attains statistical significance (North, 1972). It was, however, much less evident in the group of patients restarting treatment in week 15 (Table 6).

The scoring system cannot be directly related to the severity of the ENL, i.e. a fall of $25 \%$ in the score should not be read as equivalent to a fall of $25 \%$ in the severity of the ENL. It is clear that trials on a much larger scale will be required if it is considered desirable to demonstrate accurately the degree of improvement that occurs when dapsone treatment is discontinued for 2 or 3 months. This study, however, demonstrates incontrovertibly that ENL is not abolished by this manoeuvre, and suggests that it is only marginally affected. Further, it gives no information on the effect of lowering the dosage of dapsone during reactions. Myco. leprae is highly sensitive to dapsone (Rees, 1967) and a dosage as low as $1 \mathrm{mg}$ daily is chemotherapeutically effective (Waters, Rees and Ellard, 1968). Such low dosages, however, may predispose to the emergence of dapsone 
resistance and should be avoided in the management of lepromatous leprosy; the effect in alleviating the severity of ENL is unlikely to be great enough to be of practical value.

This small scale trial makes it clear that no great improvement in ENL can be expected even if dapsone treatment is totally discontinued for 2 or 3 months. Similarly, it is clear that initiating anti-leprosy treatment in full dosage when ENL is present does not cause a violent flare-up of the reaction. Both these findings have immediate application to the management of ENL, and could considerably simplify the problems of management of ENL for the paramedical workers who usually have responsibility for such cases.

\section{Acknowledgements}

This trial was designed in collaboration with Dr R. J. W. Rees of the National Institute for Medical Research, London. We are grateful to Dr M. K. Bhojwani, Director, National Leprosy Control Centre, Sungei Buloh, Malaysia, for the clinical assessments of patients in the trial and for advice during the preparation of this paper; to Dr D.S. Ridley, Hospital for Tropical Diseases, London, for the biopsy reports; to the Malayan Pharmaceutical Factory Sdn. Bhd., for the generous gift of dapsone and placebo capsules used in the study; and to our staff and patients for their support and co-operation. One of us (H. S. H.) wishes to thank the Malaysian Ministry of Health for permission to publish. The Leprosy Research Unit, Sungei Buloh, is jointly sponsored by the Malaysian Ministry of Health and the (British) Medical Research Council.

\section{References}

Bushby, S. R. M. (1964). Chemotherapy. In Leprosy in Theory and Practice, 2nd Ed. (Eds Cochrane and Davey) Bristol: John Wright \& Sons.

Helmy, S. H., Pearson, J. M. H. and Waters, M. F. R. (1972). Treatment of moderately severe erythema nodosum leprosum with clofazimine-a controlled trial. Lepr. Rev. 42, 167-177.

Murata, M. (1912). Ueber erythema nodosum leprosum. Japan. Ztschr. Dermat. Urol. 12, 1013-1051.

North, W. R.S. (1972). Personal communication.

Pearson, J. M. H. and Vedagiri, M. (1969). Treatment of moderately severe erythema nodosum leprosum with thalidomide-a double-blind controlled trial. Lepr. Rev. 40,111-116.

Rees, R. J. W. (1967). Drug resistance of M. leprae particularly to DDS. Int. J. Lepr. 35, 625-636.

Waters, M. F. R. (1971). An internally controlled double-blind trial of thalidomide in severe erythema nodosum leprosum. Lepr. Rev. 42, 2642.

Waters, M. F. R., Rees, R. J. W. and Ellard, G. A. (1968). Experimental and clinical studies on the minimum inhibitory concentration (MIC) of dapsone (DDS) in leprosy. Int. J. Lepr. 36,651 .

Wemambu, S. N. C., Turk, J. L., Waters, M. F. R. and Rees, R. J. W. (1969). Erythema nodosum leprosum-a clinical manifestation of the Arthus phenomenon. Lancet ii, 933-935. 